\title{
糸状菌におけるガラクトフラノース含有糖鎖の生合成
}

\author{
岡 拓二 ${ }^{1}$; 後藤 正利 ${ }^{2}$ \\ 1 崇城大学生物生命学部応用微生物工学科 \\ FAX: +81-96-323-1330, E-mail: oka@bio.sojo-u.ac.jp \\ 2 九州大学大学院農学研究院生物機能科学部門未来創成微生物学寄附講座 \\ FAX: +81-92-642-3959, E-mail: mgoto@brs.kyushu-u.ac.jp \\ (受付日：2015年4月29日, 受理日：2015年 5 月 22 日) \\ キーワード : ガラクトフラノース, 細胞壁, 糖転移酵素, 糸状菌
}

要 約

ガラクトフラノース含有糖鎖は子囊菌門のうちチャワンタケ亜門に属する糸状菌に見られる。ガラクトフラ ノース含有糖鎖は医療現場において肺アスペルギルス症の指標として広く使われており、糸状菌の細胞壁形成にお ける重要性が認識されてきたにも関わらず、その生合成に関わるガラクトフラノース転移酵素に関する情報は知ら れていなかった。2013年に我々は、モデル糸状菌Aspergillus nidulans およびヒト病原菌Aspergillus fumigatusのガラ クトフラノース含有糖鎖生合成を担うガラクトフラノース転移酵素の同定と性質決定に初めて成功した。本酵素は、 GT31 ファミリーに属する糖転移酵素であり、ゴルジ体においてUDP-ガラクトフラノースを糖供与体として O-グリ カンの非還元末端にガラクトフラノースを転移する活性を有していた。本総説では本酵素の同定までの過程、酵素 学的性質、細胞内に扔ける機能拈よび糸状菌のガラクトフラノース含有糖鎖合成について紹介する。

\section{A. はじめに}

六員環であるガラクトピラノース $\left(\mathrm{Gal}_{p}\right)$ は細菌類か らヒトに至るまで、ほとんどすべての生物に利用されてい る。しかし、生物の中には五員環であるガラクトフラノー ス $\left(\mathrm{Gal}_{f}\right)$ を生体内の糖鎖に組み込んで利用しているものが いる。 $\mathrm{Gal}_{f}$ は、結核菌をはじめとする真正細菌類、トリパ ノソーマなどの一部の原生生物、線虫類、担子菌類、一部 の子囊菌類にのみ認められるマイナーな単糖である(1)。ま た、ヒトを含む高等動物や植物は、 $\mathrm{Gal}_{f}$ 糖鎖を持たないこと から $\mathrm{Gal}_{f}$ 糖鎖の生合成経路を阻害することが副作用のない 抗菌薬や抗真菌薬㧍よび農薬の開発に繋がるとして期待さ れている。 $\mathrm{Gal}_{f}$ 糖鎖は、1930年代にはすでに子囊菌類である Penicillium charlesii が産生する多糖であるガラクトカロロー ス中に少なくとも 9-10個の $\beta 1,5$-結合した $\mathrm{Gal}_{f}$ 構造として存 在が認められていた (2)。その後、1960年代には真正細菌で ある Mycoplasma 属の細胞壁(3)、1980年代にはTrypanosoma 属およびLeishmania 属の糖脂質に $\mathrm{Gal}_{f}$ が含まれていることが それぞれ報告されている $(4,5)$ 。1992年には担子菌類である Cryptococcus neoformansにおいても培養上清中に含まれるガ ラクトキシロマンナンに $\mathrm{Gal}_{f}$ が含まれることが明らかにされ た (6)。線虫類では、2009年に $\mathrm{Gal}_{f}$ が後肧期発生に必要であ ること㧍よび $\mathrm{Gal}_{f}$ が適切な体表構造の維持を通じて寒天培地 上におけるスムーズな移動に必要であることが報告されてい る(7)。本稿では、我々が最近発見したAspergillus 属糸状菌 の $\mathrm{Gal}_{f}$ 転移酵素に関する知見を中心に、 $\mathrm{Gal}_{f}$ 含有糖鎖の生合 成について紹介したい。

\section{B. アスペルギルス属におけるガラクトフラノース糖鎖}

Aspergillus 属においては、1968年に SakaguchiらによりA. fumigatus の産生する抗原性を有する多糖であるガラクトマ ンナン（GM）のマンノースコア構造に $\mathrm{Gal}_{f}$ 側鎖が結合して いることが報告されている (8)。1980年代後半から 1990 年代 にかけて多くのアスペルギルスの細胞壁抗原を認識するモノ クローナル抗体が作製された(9-13)。それらのうち、EB-A2 と呼ばれるモノクローナル抗体は末端の $\mathrm{Gal}_{f}$ 残基を認識する 抗体として知られ、侵襲性アスペルギルス症の早期診断に用 いられている(13)。

Aspergillus 属糸状菌の $\mathrm{Gal}_{f}$ は、真菌タイプの $\mathrm{GM}$ 㧍よび $N$-グリカンやO-グリカンに含まれていることが知られてい る $(1,14)$ 。これらの糖鎖は、細胞壁の構成成分として細胞壁 中に組み込まれているものと培養液中に分泌されるものがあ る。真菌タイプの GMは、一般的によく知られている植物細 胞壁由来の GM とは全く異なる物質である $(15)$ 。真菌タイプ の GMは、9から 10 組の $\alpha 1,2$-マンノテトラオースユニットが 互いに $\alpha 1,6$-結合したマンナンコア構造に $\beta 1,5-$-テラガラク トフラノシドが $\beta 1,3-も し く は ~ \beta 1,6-$ 結合した多糖である (16)。 $N$-グリカンに付加している $\mathrm{Gal}_{f}$ にはいくつかの報告がある。 Aspergillus niger 由来 $\alpha$-ガラクトシダーゼや $\alpha$-グルコシダーゼ に結合している $N$-グリカンの非還元末端に、 $\alpha 1,2$-結合で $1 つ$ の $\mathrm{Gal}_{f}$ 残基が付加されていることが報告されている(17-19)。 また、Aspergillus fumigatusより精製されたホスフォリパーゼ $\mathrm{C}$ およびフィターゼに結合している $N$-グリカンの非還元末端 においても同様に 1,2-結合で 1 つの $\mathrm{Gal}_{f}$ 残基が付加されてい るが $\alpha / \beta$-結合様式は不明である $(20)$ 。近年、A.fumigatusに 


\section{O-mannose type glycan}

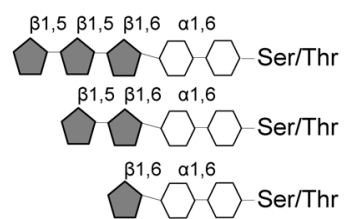

Fungal type galactomannan

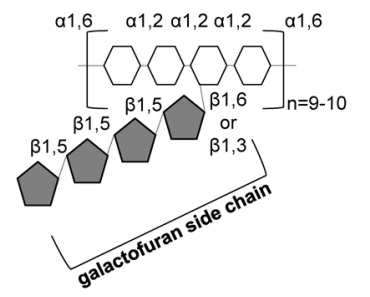

\section{$N$-glycan}
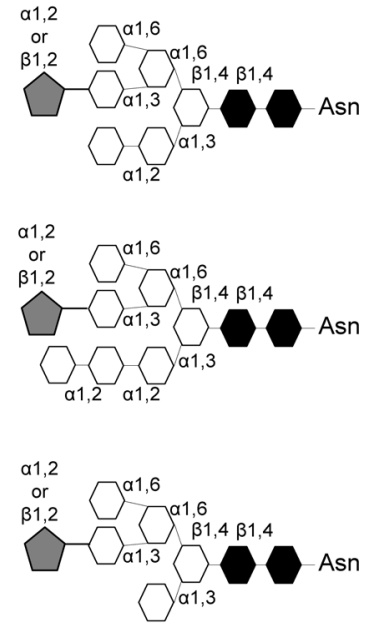

図 1.アスペルギルス属のガラクトフラノース含有 $O$-結合型糖鎖、 $N$-結合型糖鎖およびガラクトマンナンの構造。 $O$-結合型糖鎖の 構造はLeitaoらにより報告されている $(26)$ 。 $O$-結合型糖鎖は種に依存して多様な構造をもつ。 $N$-結合型糖鎖の構造は Takayanagi ら（17， 19）およびSchmalhorstら（39）によって報告されている。また、ガラクトマンナンの構造についてはLatgéら（16）によって報告され ている。GlcNAc, $N$-アセチルグルコサミン；Man、マンノース； $\mathrm{Gal}_{f}$ 、ガラクトフラノース； Ser、セリン； Thr、スレオニン；Asn、ア スパラギン酸。

おけるO-グリカンや $N$-グリカンの非還元末端側に $\beta 1,6-\mathrm{Gal}_{f}$ 結合を含むGMが付加しているという報告がなされている (21)。

糸状菌の $O$-グリカンは、 $O$-マンノース型グリカンと呼 ばれ、セリン・スレオニン残基にマンノースが付加した構造 である。O-マンノースグリカンの生合成は、小胞体に局在 するプロテイン $O$-マンノース転移酵素（Pmt）によって、ド リコールーリン酸-マンノースを糖供与体基質としてタンパク 質上のセリンもしくはトレオニン残基にマンノースが転移 されることによって始まる $(22)$ 。糸状菌において $p m t$ の破壊 は、単に糖タンパク質の $O$-マンノース鎖の減少のみではな く、正常な細胞壁や分生子の形成といった表現型に影響を与 えることが知られている $(22-26)$ 。その糸状菌の $O$-マンノー ス型グリカンの非還元末端側には $\beta 1,6$-結合で $\beta 1,5-\mathrm{Gal}_{f}$ オリ ゴ糖が付加されている $(27)$ 。タンパク質の $O$-マンノース型 グリカン修飾は、細菌類から真核生物においては酵母からヒ トまで広く分布していることが知られているが、 $\mathrm{Gal}_{f}$ にる 修飾は一部の糸状菌にのみ認められるものである。また、 $A$.

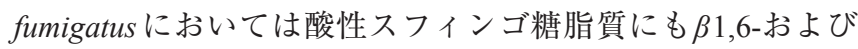
$\beta 1,2-\mathrm{Gal}_{f}$ が修飾されていることが知られている $(28)$ 。

\section{UDP-ガラクトフラノースの生合成と機能}

$\mathrm{UDP}^{-\mathrm{Gal}_{f}}$ は、 $\mathrm{Gal}_{f}$ 糖鎖生合成の糖供与体として機能す る重要な生体物質である。まず、1970年に Trejo らにより $\mathrm{UDP}-\mathrm{Gal}_{f}$ が $\mathrm{Gal}_{f}$ 糖鎖合成の中間物として機能することが明ら
かにされ(29)、1971年にはNikaidoらおよびTrejoらにより、 UDP-ガラクトピラノースから UDP-ガラクトフラノースが生 合成されていること、すなわちUDP-ガラクトピラノースム ターゼの存在が明らかにされた $(30,31)$ 。続いて、1996年に 大腸菌 K-12 株の $O$ 抗原生合成遺伝子クラスターである rfb 遺 伝子クラスター上の orf6がUDP-ガラクトピラノースムター ゼをコードしていることが示された $(32) 。$

アスペルギルス属糸状菌の $\mathrm{Gal}_{f}$ 糖鎖の生合成研究は、糖 転移酵素の糖供与体としての役割を果たす糖ヌクレオチドの 生合成酵素の同定から始まり、上記の細菌における先行研 究を基に進められた (33)。モデル糸状菌A. nidulansにおける グルコースおよびガラクトースからの UDP-Gal $\mathrm{U}_{f}$ の合成経 路を図 2 によめる。A. nidulans は、培地中にグルコースが 存在するかもしくはガラクトースが存在するかに応じて $2 つ$ の $\mathrm{UDP}_{-} \mathrm{Gal}_{f}$ の合成経路を持つ。グルコースはグルコース-6リン酸およびグルコース-1-リン酸を介してUDP-Glc $c_{p}$ へと変 換される。UDP-Glc は、 $_{p}$ 糸状菌の主要な細胞壁成分である

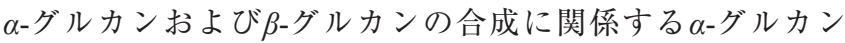
合成酵素や $\beta$-グルカン合成酵素の糖供与体であるためアス ペルギルス属の生育に必須の物質である(34-36)。 UDP-Glc の一部はUDP-グルコース4-エピメラーゼ（Uge）によって、 UDP-ガラクトピラノース $\left(\mathrm{Gal}_{p}\right)$ に変換される。A. nidulans における ugeA 遺伝子は同定され、UgeA は細胞質ゾルにおい て機能することが知られている $(37)$ 。合成された UDP-Gal ${ }_{p}$ はUDP-Gal $f$ ムターゼ $(\mathrm{Ugm} / \mathrm{Glf})$ によって、細胞質ゾルにお 


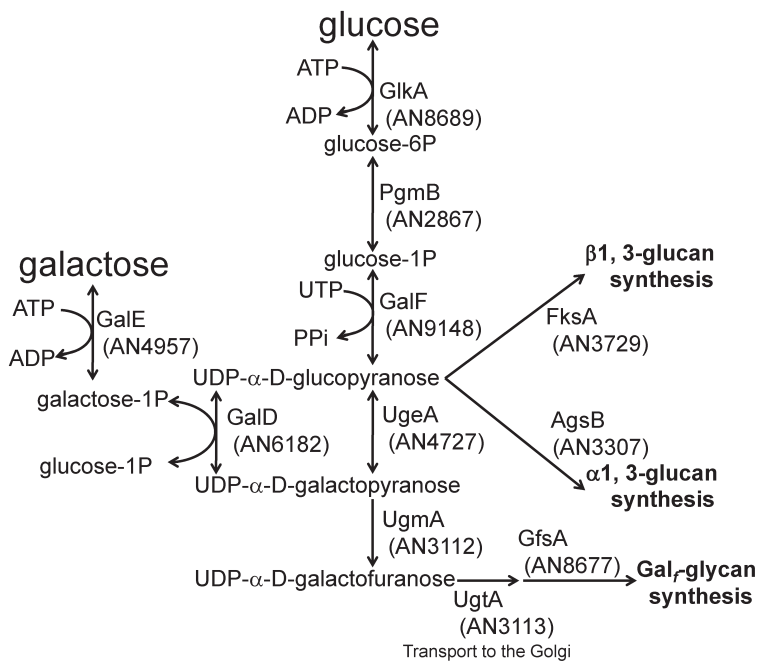

図2. Aspergillus nidulansにおけるグルコースおよびガラ

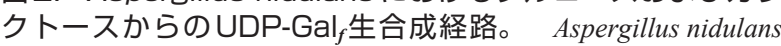
は培地中にグルコースが存在するかガラクトースが存在する かによって2つのUDP-Gal $f$ 生合成経路をもっている。UDP$\mathrm{Gal}_{f}$ は、UgeA (AN4727) およびUgmA (AN3112) によって UDP-グルコピラノース $\left(\mathrm{Glc}_{p}\right)$ より UDP-ガラクトピラノース $\left(\mathrm{Gal}_{p}\right)$ を経て合成される。グルコースを単一炭素源とすると

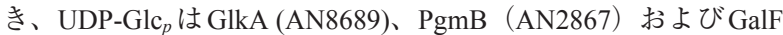
（AN9148）によってグルコースよりグルコース-6-リン酸および グルコース-1-リン酸を経て合成される。ガラクトースを単一炭 素源とするとき、UDP-Gal $f$ は、GalE (AN4957)、GalD (AN6182) およびUgmA（AN3112）によってガラクトース-1ーリン酸およ びUDP-Gal $p_{p}$ 経て合成される。UDP-Gal ${ }_{p}$ は細胞壁の主要な構

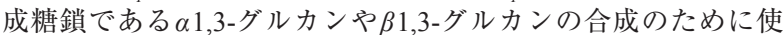
われる。UDP-Gal $f$ は、 $\mathrm{Gal}_{f}$ 糖鎖の合成に使われる。

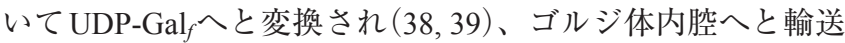
される。一方、ガラクトースによって生育させた場合、ガラ クトース-1ーリン酸およびUDP-Gal $p$ を介して UDP-Gal H $_{f}$ 合成

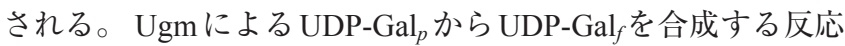
は可逆的であり、in vitroにおける実験によると平衡がUDP$\mathrm{Gal}_{p}$ の合成に傾いていることから UDP-Gal $f$ 産生の律速段階 であると考えられる $(38,40)$ 。また、GlfA（UgmA）タンパ ク質については、立体構造が明らかにされており、フラビン 補因子の酸化還元により酵素活性部位の構造変化が起こり、 活性が制御されていることが見出されている $(41,42) 。$

$\mathrm{Gal}_{f}$ 糖鎖は上記のように多様である。しかし、すべての $\mathrm{Gal}_{f}$ 糖鎖はUDP-Gal $f$ を糖供与体として合成される。それゆ えに、ugeA遺伝子や特に ugm $/$ /glfA 遺伝子を破壊することで $\mathrm{Gal}_{f}$ 糖鎖全体の機能や役割が理解できる。いくつかの報告に

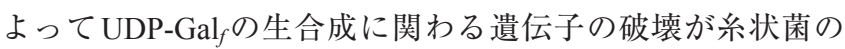
表現型に影響するということが明らかにされている。ugeA 遺伝子破壊株は、グルコースを単一炭素源とする培地上で生 育が遅れ、菌糸が高頻度に分岐しており、分生子形成能が低 下することが報告されている。これは、ugeA遺伝子破壊株 では、グルコースで培養した際にUDP-Gal ${ }_{f}$ の生合成が止まっ
てしまうからである $(37,43,44) 。$ Aspergillus nigerにおける glfA $(u g m A)$ 遺伝子破壊株では、細胞壁中のキチン合成阻害 剂であるカルコフルオロホワイトに高感受性を示した。この ことから、 $\mathrm{Gal}_{f}$ 糖鎖の合成が細胞壁インテグリティ経路を通 して $\mathrm{Gal}_{f}$ 糖鎖以外の細胞壁成分の生合成と関わっていること が示唆されている(45)。A. fumigatus の glfA 遺伝子破壊株で は、生育が遅れ、細胞壁が薄くなること、および菌体抽出物 の $\mathrm{Gal}_{f}$ 抗体による反応性が消失しており、N-グリカン未端の $\mathrm{Gal}_{f}$ 残基が欠失していることが報告されている $(46)$ 。また、 $g l f A$ 遺伝子破壊株では野生株に比べてアンフォテリシン B、 ボリコナゾール、カスポファンギン、ニッコマイシン Z に対 する感受性が高くなっており、免疫抑制マウスへの感染実験 により病原性の低下が認められている (46)。さらに、glfA 遺 伝子破壊株では、ガラスやプラスティック樹脂および呼吸器 上皮細胞への吸着能が増幅されていることが報告されている (47)。これは、糸状菌細胞壁表面のガラクトフラノースによ る覆いがなくなることによりマンナン層が露出した状態に

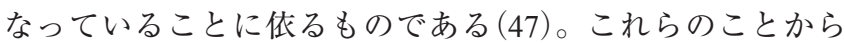
$\mathrm{Gal}_{f}$ 糖鎖の糸状菌での独特な役割の存在が示唆されている。

\section{UDP-ガラクトフラノース輸送体の発見}

細菌類における $\mathrm{Gal}_{f}$ 糖鎖生合成の場は、細胞質膜であ

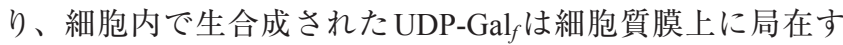
る糖転移酵素によって使われる $(48)$ 。一方、真核細胞におけ る $\mathrm{Gal}_{f}$ 糖鎖生合成の場は、ゴルジ体である。A.fumigatus の ゴルジ体に局在する UDP-Gal $f$ 輸送体（GlfB）は、細胞質ゾ ルに存在するUDP-Gal $f$ をゴルジ体内腔へと輸送し、同時に ゴルジ体内腔に輸送されたUDP-Gal $f$ が糖鎖合成に利用され ることが明らかにされた $(49,50)$ 。この遺伝子の同定のため に Engelらは、BLAST 検索を利用することにより A. fumigatus のゲノム上に 16 個の UDP-Gal $f$ 輸送体候補遺伝子を見出した (49)。その中で glfB は、シロイヌナズナの UDP-Gal $p$ 輸送体 であるAtUDP-GalT1 と 21\%のアミノ酸レベルでの相同性を 有し、染色体上で $u g m A / g l f A$ の隣に存在する遺伝子であった (49)。A. fumigatusにおいては、機能的に関係のある遺伝子 がクラスターを形成している例がしばしば見られることか ら、glfB 遺伝子を可能性の高い候補遺伝子として解析を進 めた。glfB破壊株は $u g m A / g l f A$ 破壊株と同様の表現型を示し た。glfB破壊株では、菌体抽出物の $\mathrm{Gal}_{f}$ 抗体による反応性が 消失し、 $N$-グリカン末端の $\mathrm{Gal}_{f}$ 残基が欠失していた。また、 in vitro アッセイにより GlfB と UDP-Gal ${ }_{f}$ が結合することおよ びGlfBがその他の糖ヌクレオチドを輸送している可能性が

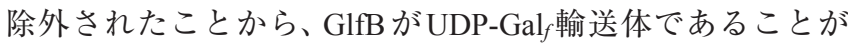
明らかにされた。GlfBの局在がゴルジ体であったことから、 糸状菌における $\mathrm{Gal}_{f}$ 糖鎖生合成の場はゴルジ体であることが 明らかになった $(49)$ 。 


\section{E. 細菌類および原生生物におけるガラクトフラノース転移 酵素}

細菌類および真核生物において UDP-Gal 生合成に必要不可欠であり、 $\mathrm{Gal}_{f}$ 転移酵素の糖供与体として 機能することが明らかにされた $(29,30)$ 。その後、研究者 の興味は $\mathrm{Gal}_{f}$ 転移酵素に注がれるようになった。まず1993 年に、原生生物であるLeishmania denovaniのリポホスホグ リカン欠失変異体 R2D2 を相補する遺伝子としてLPG1が同 定された $(51)$ 。 LPG1 は、R2D2 の膜画分に $\mathrm{Gal}_{f}$ 転移酵素活 性が検出されないこと、およびマンノース結合タンパク質 モチーフを有するII型膜タンパク質であることから $\mathrm{Gal}_{f}$ 転 移酵素であると推定されている。細菌類においては、結核 菌 Mycobacterium tuberculosis の Rv3782 およびRv3808c が $\mathrm{Gal}_{f}$ 転移酵素遺伝子であり、その産物である GlfT1 および GlfT2 は、ミコリルアラビノガラクタン複合体（mAG complex）に 含まれる $\beta 1,5-\mathrm{Gal}_{f}$ および $\beta 1,6-\mathrm{Gal}_{f}$ の繰り返し構造からなる ガラクタンを合成していることが報告された(52)。GlfTは、 decaprenyldiphosphoryl- $N$-acetylglucosaminyl-rhamnose $\left(\mathrm{C}_{50}-\mathrm{P}-\mathrm{P}\right.$ GlcNAc-Rha）を基質として $\beta 1,5-\mathrm{Gal}_{f}$ 残基および $\beta 1,6-\mathrm{Gal}_{f}$ 残基 を転移する酵素であり (48)、GlfT2 は、その後の $\beta 1,5-\mathrm{Gal}_{f}$ お よび $\beta 1,6-\mathrm{Gal}_{f}$ の繰り返し構造を合成する酵素であった $(48)$ 。 また、立体構造解析により GlfT2 は四量体であることが明ら かにされている $(53)$ 。

1996 年にNassau らにより大腸菌 K-12株の $O$ 抗原生合成 に必要な $\beta 1,6-\mathrm{Gal}_{f}$ 転移酵素を $r f b$ 遺伝子クラスター上の $\operatorname{orf} 8$ （WbbI）がコードしているという仮説が発表され (54)、2006 年にはWingらによって、WbbIが $\alpha$-グルコース残基に $\beta 1,6$-結 合で $\mathrm{Gal}_{f}$ を転移する酵素であることが生化学的に実証された (55)。

\section{F. 糸状菌のガラクトフラノース転移酵素の同定}

細菌類および原生生物においていくつかの $\mathrm{Gal}_{f} \mathrm{~T}$ 転移酵 素遺伝子が同定されたことから、ゲノム情報を利用して菌類 の $\mathrm{Gal}_{f} \mathrm{~T}$ 転移酵素遺伝子の探索が始まった。しかし、LPG1， $\mathrm{Gal}_{f} \mathrm{~T} 1, \mathrm{Gal}_{f} \mathrm{~T} 2$ およびWbbIに相同性を有するタンパク質配列 は $\mathrm{Gal}_{f}$ 糖鎖を有する菌類のゲノム上には見出されなかった。 筆者らは、新規な遺伝子を発見するために逆遺伝学的手法と 生化学的手法を組み合わせた手法により、 $\mathrm{Gal}_{f} \mathrm{~T}$ 転移酵素遺 伝子の同定を試みた。

糖鎖糖質関連酵素のデータベースである CAZy (Carbohydrate-Active enZYmes Database, http://www.cazy.org)によれば、 糸状菌A. nidulans FGSC4 ゲノム上には92の推定糖転移酵素 遺伝子が存在する $(56)$ 。一方で、基礎研究の進んでいる出芽 酵母 Saccharomyces cerevisiaeには59個、分裂酵母Schizosaccharomyces pombeには 62 個の推定糖転移酵素遺伝子が存在 する。出芽酵母および分裂酵母は、 $\mathrm{Gal}_{f}$ 糖鎖を持たないこと から $\mathrm{Gal}_{f}$ 転移酵素遺伝子も持たないと考えられる。そこで
$\mathrm{Gal}_{f}$ 転移酵素遺伝子を同定するために次のような方法で候補 遺伝子を選抜した。はじめに、配糖体の生合成に関わると考 えられるGTファミリー 1 に属する糖転移酵素遺伝子は除外 した。次に、出芽酵母を含む他の生物種において同定されて いる遺伝子のオルソログを除外した。最後に、細胞壁中に $\mathrm{Gal}_{f}$ 抗原を有する糸状菌に共通の遺伝子を選抜した。そのよ うにして 11 種の遺伝子を推定 $\mathrm{Gal}_{f}$ 転移酵素遺伝子として選 抜した。すべての遺伝子について遺伝子破壊株を構築し、遺 伝子破壊株ライブラリーより遺伝子のスクリーニングを行っ たところ、AN8677遺伝子が $\mathrm{Gal}_{f}$ 転移酵素をコードしている ことが同定された。野生株より抽出したガラクトマンノプロ テイン（GMPs）は、モノクローナル抗体であるEB-2A と反 応性を示す。EB-A2は、 $\beta 1,5-$ テトラガラクトフラノシドを

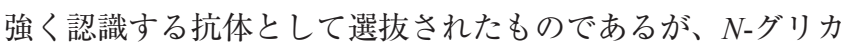
ンに付加する $\mathrm{Gal}_{f}$ 残基も認識することが知られている(13)。 AN8677破壞株より抽出した GMPsのシグナル強度は $u g m A$ 破 壊株と同様に減少していた。このことより、AN8677を galactofuranose antigen synthase A（ $g f_{s} A ）$ と名づけた $(57)$ 。

$g f_{S A}$ は 532 アミノ酸からなり、推定分子量 $60.9 \mathrm{kDa}$ の夕 ンパク質をコードしていた。GfsA は推定シグナル配列（ア ミノ酸番号：1-17アミノ酸）と推定膜貫通領域（アミノ酸 番号：18-40）をN-末端に有することから II 型膜貫通タンパ ク質であることが推察された。GfsA は他の生物間において も保存されている金属結合DXDシグナルモチーフ（アミ） 酸番号：256-258）および2つの推定 $N$-グリカン付加部位（ア ミノ酸番号：93-95および414-416）を有していた。GfsAは、 $\mathrm{CAZy}$ の分類ではGTファミリー31に属する糖転移酵素で あった。CAZy中の GT ファミリー31では、既報の糖転移酵 素としては、Fringe として知られるフコース特異的 $\beta 1,3-N-$ ア セチルグルコサミン転移酵素など(58)、少なくとも 9 種の反 応を担う酵素が登録されているが、 $\mathrm{Gal}_{f}$ 転移醳素は登録され ていない。また、細菌由来の $\beta 1,5-$-抢よび $\beta 1,6-\mathrm{Gal}_{f}$ 転移酵素 であるGlfT2はGTファミリー2に属しており、リューシマ ニア由来の $\beta 1,3-\mathrm{Gal}_{f}$ 転移酵素である LPG1 は GT ファミリー 40 に属している。GfsAの一次構造は、既知の $\mathrm{Gal}_{f}$ 転移酵素 との類似性は認められず異なっていた。

\section{G. GfsAの酵素機能と局在}

GfsAの機能解析を進めるために、A. nidulans 菌体内に おいてGfsA-3xFLAG 融合タンパク質を発現させた。GfsA3xFLAG 融合タンパク質を発現させた菌株は、GfsA-3xFLAG は $N$-グリカンが付加した $68 \mathrm{kDa}$ の糖タンパク質を産生した。 精製したGfsA-3xFLAG、糖供与体としてUDP-Gal ${ }_{f}$ 受容基 質としてWscA-HAタンパク質もしくはGMPsを用いて受容 基質 $\mathrm{Gal}_{f}$ 転移活性の検出を試みた。 $g f s A$ 破壞株より得た受容 基質を用いた時に、 $\mathrm{Mn}^{2+}$ 依存的な $\mathrm{Gal}_{f}$ 転移活性が観察され

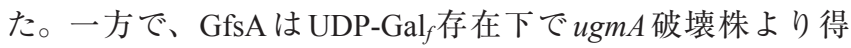


た受容基質に対して活性を示さなかった。糸状菌のO-グリ カンの構造を基に考察すれば(26)、糸状菌のO-グリカンの 生合成には少なくとも2 種類の $\mathrm{Gal}_{f}$ 転移酵素が関与している ことが考えられる。1つは $\alpha 1,6-$ マンノビオースの非還元末端 マンノース残基を糖受容体として $\beta 1,6$-結合で $\mathrm{Gal}_{f}$ を転移す る酵素であり、もう1つは、非還元末端の $\mathrm{Gal}_{f}$ 残基を糖受容 体として $\beta 1,5$-結合で $\mathrm{Gal}_{f}$ を転移する酵素である。後者の反 応には $\mathrm{Gal}_{f}$ 残基が必須である。 $\mathrm{GfsA}$ が $\mathrm{Gal}_{f}$ 糖鎖完全欠損株 より抽出したGMPを受容基質として認識しなかったという

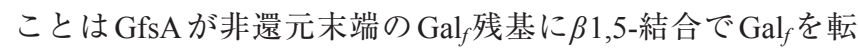
移する酥素であることを示唆しており、GfsA は、 $\beta 1,5-\mathrm{Gal}_{f}$ 転 移酵素である可能性が高いと考えられる。しかし、詳細な受 容基質の構造や GfsAの結合様式の決定には、さらなる解析 が必要である。一方、ショ糖密度勾配遠心分離法による才 ルガネラ分離によってGfsAの細胞内局在を決定したところ、 ゴルジ体に局在することが明らかになった。この局在性は、 UDP-Gal $_{f}$ 輸送体の局在と似ていた $(49,50)$ 。また、受容基質 と推定される $O$-マンノースグリカンの伸長反応が、出芽醳 母においてゴルジ体で起こることと一致していた(59)。

\section{H. $\boldsymbol{g} \boldsymbol{s} \boldsymbol{s} A$ 破壊による表現型}

A. nidulans において $g f s$ 遺伝子を破壊することにより、 さまざまな表現型の異常が生じた。 $g f s A$ 遺伝子破壊株では、 菌系の伸長速度が野生株の約 30\%減少し、形成される分生 子数が $89 \%$ 減少した。また、 $g f_{S A}$ 破壊株の菌糸は高頻度に 湾曲しており、系状菌細胞中に存在する隔壁間の平均距離が 狭まっていた。gfsA破壊株は、野生株に比べて、細胞壁合成 阻害剂に対する感受性が変化していた。したがって、O-グ リカン部分の $\beta 1,5-\mathrm{Gal}_{f}$ 糖鎖が $A$. nidulans の細胞形態や分生子 形成の過程で何らかの重要な役割を担っていることが推察さ れた。また、ヒトの日和見感染症である肺アスペルギルス症 の原因菌A. fumigatus のA. nidulans $g f_{S} A\left(A n g f_{S} A\right)$ の推定才 ルソログであるAFUB_096220をAfgfsA と名づけ、遺伝子破 壞株を取得するとともに、野生株との表現型の差異を解析し た。その結果、Afgfs $A$ 破壊株では、培養温度 47 度という高 温条件下に打いて 30-37度培養条件下に扔ける Ang $f s A$ 破壊 株と同様に白く小さいコロニー形態を示した。また、Afgfs 破壞株では Ang fsA 破壊株と同様に GMP 中の $\mathrm{Gal}_{f}$ 糖鎖が減少 していた。A.fumigatusにおけるAfgfsAの破壊による菌体成 長に扔ける影響は限定的であった。このことは、A. fumigatus における glfA 破壞による影響がA. nidulans の ugmA 破壊によ

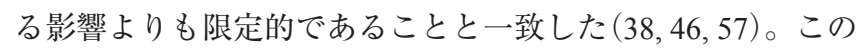
ことは、A. nidulansにおいて $\mathrm{Gal}_{f}$ 糖鎖の細胞壁形成における 寄与度がA. fumigatusよりも高いことを示している。

\section{I. ガラクトフラノース糖鎖生合成遺伝子の分布}

$g f_{s} A$ のルソログは、子囊菌門のうちチャワンタケ亜
門に属する真菌に分布する。チャワンタケ亜門は、いもち病 原菌であるMagnaporthe oryzaeや白鮮菌である Trichophyton rubrum な゙多くの植物病原菌や人畜病原菌を含み、子囊菌 門のうちもっとも大きな分類群である。また、ugmA/glfA お よび $u g t A / g l f B$ のオルソログも $g f s A$ と同様にチャワンタケ亜 門に属する真菌類が保持していた。これは、ugmA/glfA, ugtA/ $g l f B$ 抢よび $g f_{S} A$ が一連の $\mathrm{Gal}_{f}$ 糖鎖合成経路上にあることを 考えれば理にかなっていた。一方で、同じ子囊菌門のうち Saccharomyces cerevisiae や Candida albicans が属するサッカロ ミセス亜門やSchizosaccharomyces pombeが属するタフリナ菌 亜門に属する菌は $g f_{S} A$ を持たない。また、接合菌門に属す るRhizopus oryzaeもgfsAを持たない。このことは、これら の菌類が $\mathrm{Gal}_{f}$ 糖鎖を持たないことと一致した。これらの菌類 は、一連の $\mathrm{Gal}_{f}$ 糖鎖合成経路である ugmA/glfA, ugtA/glfB も持 たない。

一方で、担子菌門に属するCryptococcus neoformans や Ustilago maydisでは gfsA は存在せず、ugmA/glfA およびugtA/ glfBのみが存在していた。C. neoformansの形成するカプセ ルの多糖には、 $\beta 1,2-\mathrm{Ga}_{f}$ 糖鎖が含まれており、また、C. neoformans の O-グリカンに $\mathrm{Gal}_{f}$ 糖鎖が存在することは知られ ていない。すなわちこのことは、C. neoformansは、 $\mathrm{Gal}_{f}$ 糖鎖 を持っているが GfsAが転移する $O$-グリカンの $\beta 1,2-\mathrm{Gal}_{f}$ 糖鎖 は持っていないという事実と一致した。担子菌類の持つ $\mathrm{Gal}_{f}$ 糖鎖生合成には全く別の糖転移酵素が関わっていると考えら れる。

\section{H. おわりに}

子囊菌門のチャワンタケ亜門に属する菌類や担子菌門 に属する菌類は、多様な構造の $\mathrm{Gal}_{f}$ 糖鎖を有している。それ ゆえ、これら菌類の多様な $\mathrm{Gal}_{f}$ 糖鎖の生合成に関わる多様な

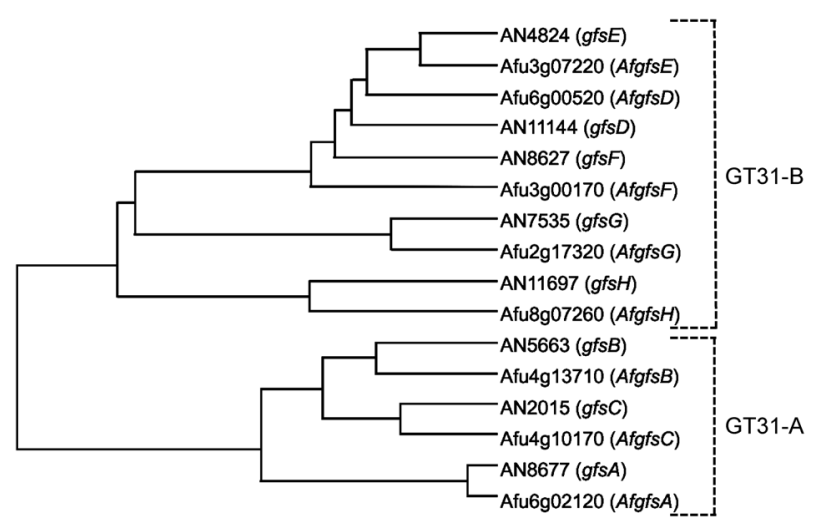

図3. Aspergillus nidulansおよびAspergillus fumigatus の Gfs タンパク質の進化系統樹。A. nidulans および $A$. fumigatus は7つの $g f_{s} A$ ホロログを有している。それらのタンパ ク質を GfsBから GfsH と名付けた。Gfs タンパク質は進化系統 的にGT31-A と GT31-Bのグループに大別された。これらのホ モログは、GfsA とは基質認識や結合様式が異なる $\mathrm{Gal}_{f}$ 転移酵素 であることが予想される。 
$\mathrm{Gal}_{f}$ 転移酵素は、いまだ宝物として眠っている。ゲノム情報 によるとA. nidulans およびA. fumigatusにはgfsAの推定ホモ ログが7つ存在するが、機能は明らかにされていない。それ ぞれのタンパク質に、それぞれ GfsBから GfsHまで名前を付 けた。これらのホモログは、GfsA とは異なる基質認識や結 合様式を持つ $\mathrm{Gal}_{f}$ 転移酵素であることが予想される。進化系
統樹によると Gfs タンパク質は2つのグループに大別できる ことが明らかになった（図3）。Gal 糖鎖は多くの植物および 人畜病原菌にも含まれている。 $\mathrm{Gal}_{f}$ 転移酵素群の解析により、 病原菌の病原性や感染メカニズムにおける $\mathrm{Gal}_{f}$ 糖鎖の役割が 明らかにされることも期待したい。

\section{参考文献}

1. Tefsen, B., Ram, A. F., van Die, I., and Routier, F. H. (2012) Glycobiology 22, 456-469.

2. Haworth, W. N., Raistrick, H., and Stacey, M. (1937) Biochem. J. 31, 640-644.

3. Plackett, P., and Buttery, S. H. (1964) Biochem. J. 90, 201-205.

4. de Lederkremer, R. M., Casal, O. L., Alves, M. J., and Colli, W. (1980) FEBS Lett. 116, 25-29.

5. Turco, S. J., Orlandi, P. A. Jr., Homans, S. W., Ferguson, M. A., Dwek, R. A., and Rademacher, T. W. (1989) J. Biol. Chem. 264, $6711-6715$.

6. James, P. G., and Cherniak, R. (1992) Infect. Immun. 60, 1084-1088.

7. Novelli, J. F., Chaudhary, K., Canovas, J., Benner, J. S., Madinger, C. L., Kelly, P., Hodgkin, J., and Carlow, C. K. (2009) Dev. Biol. $335,340-355$.

8. Sakaguchi, O., Suzuki, M., and Yokota, K. (1968) J. Microbiol. 12, 123-124.

9. Bennett, J. E., Bhattacharjee, A. K., and Glaudemans, C. P. (1985) Mol. Immunol. 22, 251-254.

10. de Repentigny, L., Boushira, M., Ste-Marie, L., and Bosisio, G. (1987) J. Clin. Microbiol. 25, 863-867.

11. Ste-Marie, L., Sénéchal, S., Boushira, M., Garzon, S., Strykowski, H., Pedneault, L., and de Repentigny, L. (1990) Infect. Immun. 58, $2105-2114$.

12. Haynes, K. A., Latge, J. P., and Rogers, T. R. (1990) J. Clin. Microbiol. 28, 2040-2044.

13. Stynen, D., Sarfati, J., Goris, A., Prévost, M. C., Lesourd, M., Kamphuis, H., Darras, V., and Latgé, J. P. (1992) Infect. Immun. 60, $2237-2245$.

14. Goto, M. (2007) Biosci. Biotechnol. Biochem. 71, 1415-1427.

15. Prajapati, V. D., Jani, G. K., Moradiya, N. G., Randeria, N. P., Nagar, B. J., Naikwadi, N. N., and Variya, B. C. (2013) Int. J. Biol. Macromol. 60, $83-92$.

16. Latgé, J. P., Kobayashi, H., Debeaupuis, J. P., Diaquin, M., Sarfati, J., Wieruszeski, J. M., Parra, E., Bouchara, J. P., and Fournet, B. (1994) Infect. Immun. 62, 5424-5433.

17. Takayanagi, T., Kimura, A., Chiba, S., and Ajisaka, K. (1994) Carbohydr. Res. 256, 149-158.

18. Wallis, G. L., Easton, R. L., Jolly, K., Hemming, F. W., and Peberdy, J. F. (2001) Eur. J. Biochem. 268, 4134-4143.

19. Takayanagi, T., Kushida, K., Idonuma, K., and Ajisaka, K. (1992) Glycoconj. J. 9, 229-234.

20. Morelle, W., Bernard, M., Debeaupuis, J. P., Buitrago, M., Tabouret, M., and Latgé, J. P. (2005) Eukaryot. Cell 4, $1308-1316$.

21. Kudoh, A., Okawa, Y., and Shibata, N. (2015) Glycobiology 25, 74-87.

22. Oka, T., Hamaguchi, T., Sameshima, Y., Goto, M., and Furukawa, K. (2004) Microbiology 150, 1973-1982.

23. Shaw, B. D., and Momany, M. (2002) Fungal Genet. Biol. 37, 263-270.

24. Oka, T., Sameshima, Y., Koga, T., Kim, H., Goto, M., and Furukawa, K. (2005) Microbiology 151, 3657-3667.

25. Goto, M., Harada, Y., Oka, T., Matsumoto, S., Takegawa, K., and Furukawa, K. (2009) Eukaryot. Cell 8, 1465-1474.

26. Kriangkripipat, T., and Momany, M. (2009) Eukaryot. Cell 8, 1475-1485.

27. Leitao, E. A., Bittencourt, V. C., Haido, R. M., Valente, A. P., Peter-Katalinic, J., Letzel, M., de Souza, L. M., and Barreto-Bergter, E. (2003) Glycobiology 13, 681-692.

28. Guimarães, L. L., Toledo, M. S., Ferreira, F. A., Straus, A. H., and Takahashi, H. K. (2014) Front. Cell Infect. Microbiol. 4, 138.

29. Trejo, A. G., Chittenden, G. J., Buchanan, J. G., and Baddiley, J. (1970) Biochem. J. 117, 637-639.

30. Nikaido, H., and Sarvas, M. (1971) J. Bacteriol. 105, 1073-1082.

31. Trejo, A. G., Haddock, J. W., Chittenden, G. J., and Baddiley, J. (1971) Biochem. J. 122, 49-57.

32. Nassau, P. M., Martin, S. L., Brown, R. E., Weston, A., Monsey, D., McNeil, M. R., and Duncan, K. (1996) J. Bacteriol. 178, $1047-1052$.

33. Bakker, H., Kleczka, B., Gerardy-Schahn, R., and Routier, F. H. (2005) Biol. Chem. 386, 657-661.

34. Kelly, R., Register, E., Hsu, M. J., Kurtz, M., and Nielsen, J. (1996) J. Bacteriol. 178, 4381-4391.

35. Beauvais, A., Maubon, D., Park, S., Morelle, W., Tanguy, M., Huerre, M., Perlin, D. S., and Latgé, J. P. (2005) Appl. Environ. Microbiol. 71, 15311538.

36. Yoshimi, A., Sano, M., Inaba, A., Kokubun, Y., Fujioka, T., Mizutani, O., Hagiwara, D., Fujikawa, T., Nishimura, M., Yano, S., Kasahara, S., Shimizu, K., Yamaguchi, M., Kawakami, K., and Abe, K. (2013) PLoS ONE 8, e54893.

37. El-Ganiny, A. M., Sheoran, I., Sanders, D. A., and Kaminskyj, S. G. (2010) Fungal Genet. Biol. 47, 629-635.

38. El-Ganiny, A. M., Sanders, D. A., and Kaminskyj, S. G. (2008) Fungal Genet. Biol. 45, 1533-1542.

39. Schmalhorst, P. S., Krappmann, S., Vervecken, W., Rohde, M., Müller, M., Braus, G. H., Contreras, R., Braun, A., Bakker, H., and Routier, F. H. (2008) Eukaryot. Cell 7, 1268-1277.

40. Oppenheimer, M., Poulin, M. B., Lowary, T. L., Helm, R. F., and Sobrado, P. (2010) Arch. Biochem. Biophys. 502, 31-38.

41. Dhatwalia, R., Singh, H., Oppenheimer, M., Karr, D. B., Nix, J. C., Sobrado, P., and Tanner, J. J. (2012) J. Biol. Chem. $287,9041-9051$.

42. van Straaten, K. E., Routier, F. H., and Sanders, D. A. (2012) J. Biol. Chem. 287, 10780-10790.

43. Lee, M. J., Gravelat, F. N., Cerone, R. P., Baptista, S. D., Campoli, P. V., Choe, S. I., Kravtsov, I., Vinogradov, E., Creuzenet, C., Liu, H., Berghuis, A. M., Latgé, J. P., Filler, S. G., Fontaine, T., and Sheppard, D. C. (2014) J. Biol. Chem. 289, 1243-1256. 
44. Park, J., Tefsen, B., Arentshorst, M., Lagendijk, E., van den Hondel, C. A., van Die, I., and Ram, A. F. (2014) Fungal Biol. Biotechnol. 1, 6.

45. Damveld, R. A., Franken, A., Arentshorst, M., Punt, P. J., Klis, F. M., van den Hondel, C. A., and Ram, A. F. (2008) Genetics 178, $873-881$.

46. Schmalhorst, P. S., Krappmann, S., Vervecken, W., Rohde, M., Müller, M., Braus, G. H., Contreras, R., Braun, A., Bakker, H., and Routier, F. H. (2008) Eukaryot. Cell 7, 1268-1277.

47. Lamarre, C., Beau, R., Balloy, V., Fontaine, T., Wong Sak Hoi, J., Guadagnini, S., Berkova, N., Chignard, M., Beauvais, A., and Latgé, J. P. (2009) Cell. Microbiol. 11, 1612-1623.

48. May, J. F., Splain, R. A., Brotschi, C., and Kiessling, L. L. (2009) Proc. Natl. Acad. Sci. U.S.A. 106, 11851-11856.

49. Engel, J., Schmalhorst, P. S., and Routier, F. H. (2012) J. Biol. Chem. 287, 44418-44424.

50. Afroz, S., El-Ganiny, A. M., Sanders, D. A., and Kaminskyj, S. G. (2011) Fungal Genet. Biol. 48, 896-903.

51. Ryan, K. A., Garraway, L. A., Descoteaux, A., Turco, S. J., and Beverley, S. M. (1993) Proc. Natl. Acad. Sci. U.S.A. 90, 8609-8613.

52. Belánová, M., Dianisková, P., Brennan, P. J., Completo, G. C., Rose, N. L., Lowary, T. L., and Mikusová, K. (2008) J. Bacteriol. 190, $1141-1145$.

53. Wheatley, R. W., Zheng, R. B., Richards, M. R., Lowary, T. L., and Ng, K. K. (2012) J. Biol. Chem. 287, $28132-28143$.

54. Nassau, P. M., Martin, S. L., Brown, R. E., Weston, A., Monsey, D., McNeil, M. R., and Duncan, K. (1996) J. Bacteriol. 178, $1047-1052$.

55. Wing, C., Errey, J. C., Mukhopadhyay, B., Blanchard, J. S., and Field, R. A. (2006) Org. Biomol. Chem. 4, 3945-3950.

56. Campbell, J. A., Davies, G. J., Bulone, V., and Henrissat, B. (1997) Biochem. J. 326, 929-939.

57. Komachi, Y., Hatakeyama, S., Motomatsu, H., Futagami, T., Kizjakina, K., Sobrado, P., Ekino, K., Takegawa, K., Goto, M., Nomura, Y., and Oka, T. (2013) Mol. Microbiol. 90, 1054-1073.

58. Moloney, D. J., Panin, V. M., Johnston, S. H., Chen, J., Shao, L., Wilson, R., Wang, Y., Stanley, P., Irvine, K. D., Haltiwanger, R. S., and Vogt, T. F. (2000) Nature 406, 369-375.

59. Lussier, M., Sdicu, A. M., and Bussey, H. (1999) Biochim. Biophys. Acta 1426, 323-334.

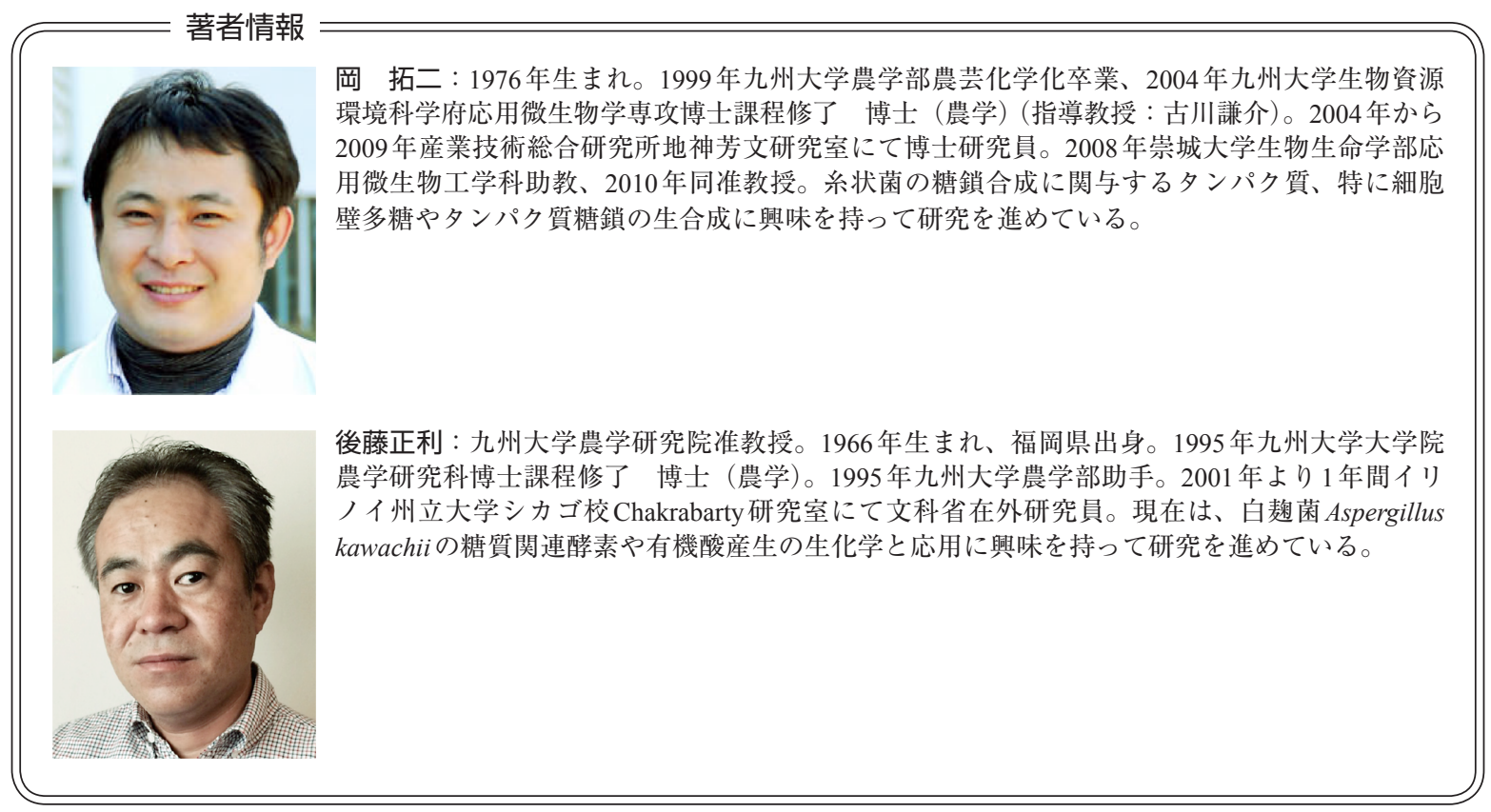

